\title{
Government, the private, and local communities in ecosystem restoration governance and practices
}

\author{
YANTO ROGHMAYANTO \\ Center for Instrument Standardization of Disaster Resilience and Climate Change / \\ Pusat Standarisasi Instrumen Ketahanan Bencana dan Perubahan Iklim, Jl Gunung Batu No 5, Bogor 161 18, Indonesia
}

Corresponding author: rochmayantoyr@yahoo.co.uk

Submitted 4 October 2021; Accepted 13 October 2021

\begin{abstract}
Ecosystem restoration is not only a concern for countries such as Indonesia, but has become a global concern, as the UN has announced the Decade on Ecosystem Restoration for 2021-2030. Ecosystem restoration is an important way of restoring degraded landscapes, ensuring the sustainability of biodiversity, as well as being an effective pathway for reducing emissions. Indonesia has committed to ecosystem restoration through national statutory law since 2004, although it is no longer explicitly listed in the Omnibus Las No. 11 of 2020 and Government Regulation No. 23 of 2021 on Forestry Stewardship. Indonesia has demonstrated good progress in the implementation of ecosystem restoration in several priority provinces coordinated by the Peat and Mangrove Restoration Agency, as well as in initiatives led by the private sector. Although both involved rural communities in restoration activities, I propose here that an innovative ecosystem restoration business model is necessary to make their participation more financially attractive to local communities. This paper provides an analysis of progress and the needs for ecosystem restoration improvement in Indonesia.
\end{abstract}

\begin{abstract}
ABSTRAK
Restorasi ekosistem saat ini bukan hanya menjadi perhatian negara tertentu seperti Indonesia, tetapi telah menjadi perhatian dunia, sebagaimana UN telah mencanangkan periode restorasi ekosistem tahun 2021-2030. Restorasi ekosistem merupakan hal yang sangat penting untuk pemulihan lanskap yang terdegradasi, menjamin keberlangsungan biodiversitas yang sangat kaya, serta menjadi pathway penurunan emisi sektor berbasis lahan. Indonesia telah menunjukkan komitmen restorasi ekosistem dalam regulasi nasional sejak 2004, walaupun secara eksplisit tidak lagi tercantum dalm Omnibus Las No 11 tahun 2020 dan Peraturan Pemerintah No 23 Tahun 2021 tentang Penyelenggaraan Kehutanan. Indonesia juga telah mendemonstrasikan capaian yang cukup baik pada pelaksanaan restorasi ekosistem di sejumlah provinsi prioritas yang dikoordinasikan oleh BRGM, dan juga rinisiatif restorasi ekosistem yang dilakukan oleh sektor swasta. Keduanya memang melibatkan masyarakat dalam pelaksanaan restorasi, namun dipandang perlu untuk menciptakan model bisnis restorasi ekosistem yang inovatif agar lebih atraktif secara finansial bagi kelompok masyarakat. Paper ini akan menganalisis progress dan kebutuhan tersebut untuk kepentingan peningkatan kualitas restorasi ekosistem di Indonesia.
\end{abstract}

Keywords: business model, community, ecosystem restoration, private sector

\section{INTRODUGTION}

The UN General Assembly has declared the UN Decade on Ecosystem Restoration to catalyse massive ecosystem restoration efforts on damaged and disturbed ecosystems in 2021-2030 (IUCN, 2021). Forest ecosystem restoration in particular is considered an effective pathway to restoring landscapes and mitigating climate change. It is also increases food security, protects biodiversity, and maintains the water balance.

Indonesia has demonstrated significant concern for the restoration of degraded ecosystems and habitats. Indonesia aims to restore all its degraded land, a total of 27.5 million ha, by 2040 through various approaches, assuming no further land is degraded during 2015-2040 (Republic of Indonesia, 2015).
There are critical reasons why ecosystem restoration is important. Firstly, Indonesia has a long history of emergence of degraded land, indicated by the pattern of deforestation and forest degradation from 1990 until today. Deforestation peaked in 1996-2000 , when 3.51 million ha were lost, but, fortunately, this continues to decrease to now. From 2017 to 2019, annual deforestation was no more than 0.5 million ha per year (MoEF, 2020). Indonesia's National Forest Monitoring System recorded the average rate of forest degradation from 1990 to 2019 as 21 1,153 ha per year (Ditjen PKTL, 2020). In addition, the Ministry of Environment and Forestry reported that the total critical land area was $14,006,450$ ha in 2018, of which the critical land area inside forest areas was 8.35 million ha and the rest outside forest areas or other land uses area (Areal Penggunaan Lain or APL). The largest critical land area is 
on Sumatra (4.5 million ha), and the lowest on the Maluku Province (687,496 ha) (KLHK, 2018). This implies not only the need to avoid deforestation and for forest degradation strategies, but also the need to restore those deforested and degraded forest ecosystems.

Secondly, the need for ecosystem restoration arises due to the importance of saving the mega-biodiversity in Indonesia's forest ecosystems, particularly characterized by extremely high endemism. Indonesia consists of 13 land-based ecosystems and six aquatic ecosystems (including both freshwater and marine ecosystems). Within these 19 ecosystems, there are 74 systems of vegetation (MoEF, 2020a). In addition, Indonesia is home to 1,605 species of birds, 723 species of reptiles, 385 species of amphibians, 720 species of mammals, 1,248 species of freshwater fish, 197,964 species of invertebrates, 5,137 species of arthropods, and 151,847 species of insects, including 30,000 Hymenoptera (wasps, bees and ants). There are also 91,251 species of spore-based plants. Within the spermatophytes (plants that produce seeds), there are 120 species of vascular plants that produce exposed seeds (gymnosperms) and an estimated 30,000 to 40,000 species of flowering plants (angiosperms), of which only 19,112 species have been identified so far (Bappenas, 2016). Indonesia's tropical peat ecosystems contain rich and distinctive flora and fauna, with high ecological value. Of the 258,650 species of trees recorded in the world, about 13-15\% (about $35,000-40,000$ species) are found in Indonesia's peat ecosystems (Osaki, et al, 2016). Some 35 species of mammals, 150 species of birds, and 34 species of fish are also found in peatlands. Many species are endemic and have been on the IUCN Red List since 2012, including the False Gharial, Thomas's Langur, Orangutan, Sumatran Tiger, and Sun Bear (WWF, 2009).

Thirdly, climate change mitigation pathways through enhancing the forest carbon stock from restoration ecosystem contributes to $21 \%$ of total pantropical mitigation potential (Griscom, et al., 2020). Although forest restoration may involve trade-offs with alternative land uses, it can incur high costs of establishment, and is more expensive than Avoided Forest Conversion, as with most forest pathways, both forest restoration and reforestation provide well-demonstrated co-benefits, including biodiversity habitat, air filtration, water filtration, flood control, and enhanced soil fertility (Griscom et al, 2017).

Forest restoration in Indonesia has become a national policy priority. However, progress so far has not met government targets. Therefore, it is very important to revisit the role of the government, the private sector, local communities, and other entities in accelerating ecosystem restoration in Indonesia.

\section{EXISTING CONGEPT OF ECOSYSTEM RESTORATION}

Ecosystem restoration is intended as an effort to restore the structure, productivity, and diversity of forest species to their initial conditions so that the processes and functions of the forest ecology will be the same or close to their initial conditions (Rochmayanto, et al., 2020). This definition is in line with ITTO \& IUCN (2005), who underline forest restoration as a process aiming to restore the ability of forest ecosystems that have been degraded or deforested to support or maintain forest ecological processes and their rich biodiversity and to improve human well-being. When ecosystem degradation can be reversed and the sustainability of historical conditions is still possible to improve through management actions, standard approaches can be used to restore the ecosystem. However, if assessment of the degradation level shows that the ecosystem cannot be restored, then the management option to build a new ecosystem can be considered (Hulvey et al., 2013).

Stanturf, et al. (2017), explained more detail and promoted the mechanism and trajectory of change in ecosystem as illustrated by Figure 1. Successful ecosystem restoration must include the starting point and desired endpoint. Historical ecosystem conditions or existing reference ecosystem can be a guide for targetted ecosystem in the future. It is possible to use different trajectory to get an expected endpoint fit with existing social footprint. A diversity of new forest and non-forest habitats may best be suited to meet multiple social needs.

Strategies for ecosystem restoration do not only consider hydrological, edaphic, and vegetative components, but also social-economic perspectives on the landscape. Currently, `strategies of forest ecosystem restoration can be viewed from several perspectives based on scale of restoration, intensity of vegetative interventions, and strata of restoration. (Rochmayanto, et al., 2020; Rochmayanto et al., 2021). Scale of restoration refers to restoration activities focused on particular units of the ecosystem area. Intensiveness of intervention refers to the extent of the intervention of revegetation activities in restoring the forest. The strata of restoration draws level of ecosystem restoration activities both on physical activities and other non-vegetative approaches based on the destruction level of the ecosystem.

Scale of restoration is divided into two types, namely large-scale and mosaic restoration (IUCN \& WRI, 2014). Large-scale restoration involves several unit areas of contiguous degraded land or fragmented land, or the adjacent land uses area. Mosaic restoration describes restoration activities in a particular land use area only, such as agriculture land, agroforestry system, improvement of denuded areas, ecological corridors, 


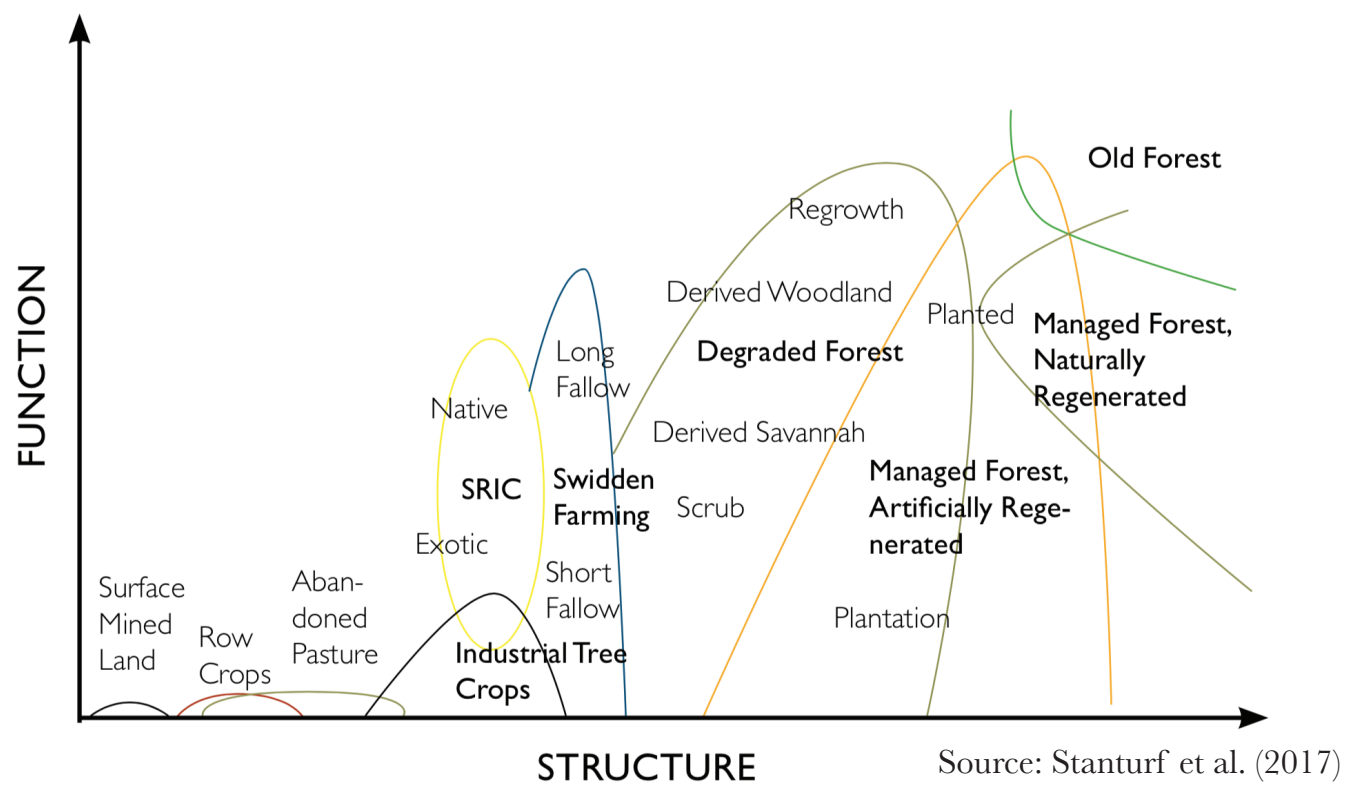

Figure 1. Conceptual model of land use condition based on vegetation structure and ecosystem function

forest area, and planting riparian zones to control water flow.

Concerning intensity of vegetative intervention, ecosystem restoration in principle can be achieved through four main approaches: natural succession, supporting natural succession, enrichment, and planting (JICA, 2014). Selection of approach depends on the terms and conditions that are appropriate, and can be used in combination in one area as needed to adjust to the site characteristics. The last perspective is the level of restoration that reflects the level of ecosystem recovery activities required as a logical consequence of the severity of degradation. This restoration level does not only involve revegetation actions, but also civil and technical engineering. For example, the following strata of ecosystem restoration have been introduced by Suryadiputra et al. (2018), among other: back filling, rewetting, drying, firebreaks, canal blocking, and topsoil introduction.

In addition, forest ecosystem restoration needs to assess the social footprint of the targeted restoration area. Social footprint refers to the extent local communities depend on the targeted restoration area. Historical land use and household economic dependency on such areas can be used as social footprint indicators. Such indicators need to be used in line with biophysical indicators of the targeted area. Biophysical assessment variables include geographical condition, hydrology, geology, land cover and land cover change. Designing any restoration ecosystem strategy must involve combining those variables with the social footprint identification results.

Restoration does not just focus on planting-related activities, such as species selection or plant autecology and phenology. Forest ecosystem recovery through natural succession is a high priority. Therefore, restoring soil and hydrological conditions, as well as protection of the restoration site against land degradation drivers are crucial components of restoration activities. In the context of forest and land degradation, MoEF (2020) officially noted that the causes of deforestation and forest degradation comprise, among other factors, intensive logging of natural forests in timber concessions, conversion of forest areas for other sectors (agricultural expansion, estate crops, mining, plantations, and transmigration), unsustainable forest management, illegal logging, encroachment, and fires. This is in line with scholarly analyses of the drivers of deforestation in Indonesia that include both direct and underlying causes. Most of deforestation is driven by expansion of crop plantation, agriculture (small and commercial scale), industrial plantation, and mining, and includes structural factors, market failure, and unsecure property rights (Rowling, 2020; Austin et al., 2019; Motel et.al., 2011).

\section{AN UPDATE OF ECOSYSTEM RESTORATION WITHIN NATIONAL FRAMEWORK}

At the global level, Indonesia has committed to actively restoring degraded ecosystems, for example, ratification of the three Rio conventions related with the issue of land degradation and habitat loss: Law No. 6 of 1994 ratifying the United Nations Framework Convention on Climate Change (UNFCCG), Law No. 5 of 1994 ratifying the Convention on Biological Diversity (CBD), and Presidential Decrees. Number 135 of 1998 ratified the United Nations Convention to Combat Desertification (UNCCD).

Ecosystem restoration has been included in the Indonesian regulatory system since 2004, on the Minister of Forestry Regulation No. 159 / 2004 concerning 
Ecosystem Restoration in Production Forest Areas. This regulation was followed by Minister of Forestry Regulation No. 18 of 2004 regulating Criteria for Production Forests that Can Be Granted Business Permits for Utilization of Timber Forest Products in Natural Forests with Ecosystem Restoration Activities. By 2007, ecosystem restoration was appointed in a higher regulatory system, namely Government Regulation No. 6 / 2007 Jo Government Regulation No. 3 / 2008 concerning Forest Management and Preparation of Forest Management Plans and Forest Utilization. The Government Regulation strengthens the implementation of restoration ecosystem mechanism that is made in the business permit scheme for the use of ecosystem restoration timber forest products.

The issuance of Government Regulation No. 23/2021 on Forestry Stewardship as a derivative of Omnibus Law No. 11 / 2020 led to the end of the Government Regulation No. 6/2007. Unfortunately, although the new Government Regulation is quite comprehensive, the term "ecosystem restoration" is no longer included. This raises the question of whether ecosystem restoration is still in the regulatory system in Indonesia.

There are two interpretations of this issue. The first interpretation is that ecosystem restoration was removed from Omnibus Law No. 11 of 2020 and then placed (implicitly) in one of its derivative forestry regulations (Government Regulation No. 23/2021) through the forests use in environmental service businesses. One of these forest services is carbon sequestration, as has been implemented by several companies holding ecosystem restoration concession permits. Another interpretation is that the current ecosystem restoration terminology no longer exists in the Indonesian regulatory system, because in Government Regulation No 23/2021, the business of utilizing timber forest products is separated and is not the same as the business of utilizing environmental services. Ecosystem restoration permit is part of the use of wood forest product, previously known as the business permit for the use of wood forest products from ecosystem restoration (IUPHHK-RE) (Susteyo, 2021).

Even so, to date, restoration ecosystem-related programmes and interventions have been widely initiated, for example:

a. Ecosystem restoration focused on peatlands. Indonesia, as stated in the Nationally Determined Contribution (NDC) (a commitment documents submitted to the UNFCGC outlines Indonesia's transition to low-emissions and climate-resilient future), set a peat restoration target of 2.5 million ha (including 684,638 ha in protected peat ecosystems, $1,410,943$ ha in cultivated peat ecosystems, and 396,943 ha in community cultivated peat ecosystems) (KLHK, 2018). Priority areas covered seven fire-prone provinces (Riau, South Sumatra,
Jambi, Central Kalimantan, West Kalimantan, South Kalimantan, and Papua), through rewetting, revegetation, and rural livelihood revitalization activities.

b. By 2020, forest ecosystem restoration commitments were extended not only in peat ecosystems, but also in mangroves ecosystems. This was followed by the enactment of Presidential Regulation No. 120/2020 concerning the Peat and Mangrove Restoration Agency (Badan Restorasi Gambut dan Mangrove, BRGM). The peat restoration target was extended by 1.2 million ha, and the mangrove restoration target was 600,000 ha in nine priority provinces.

c. Forest and land rehabilitation involving central and local governments, concession permit holders, NGOs, and local communities. During 2015-2019, the programme rehabilitated 995,253 ha, with an average productivity of around 200,000 ha/year. In addition, the civil-technical rehabilitation built 35,743 units of soil and water conservation infrastructure during the same period (Rochmayanto et al., 2020).

Along with submission of Updated NDG by 2021, Indonesia also submitted the Long-Term Strategy for Low Carbon and Climate Resilience 2050 (LTS-LCGR) to the UNFGCG. The LTS-LGGR document (as mandated by Act 4.19) described the Government's vision of climate change efforts and its proposed actions up to 2050. It was not a mandatory commitment and non-legally binding so far, but it can be tracked and reported. Indonesia expects to accelerate GHG emission reduction towards Net Sink FOLU, as outlined in the LTS-LCGR document. The Net Sink FOLU is a long-term vision in the LTS document towards net zorro emission, where the FOLU emission path is expected to reach a net sink by 2030 Three out of seven main programmes towards Net Sink FOLU by 2030 imply restoration activities: (1) increasing the capacity of natural forests for carbon sequestration (through reducing degradation and increasing regeneration), (2) restoration and improvement of peat water systems, and (3) forest restoration and rehabilitation (plant enrichment/increased carbon sequestration). Based on the LCCP scenario (Low Carbon Compatible with Paris Agreement), the targets for improving peat management and peat water management are 0.95 million ha by 2030 and a further 1.05 million ha by 2050. Furthermore, targets for peat restoration are 2.7 million ha by 2030 and 4.22 million ha by 2050 . 


\section{EXTENDING RESTORATION PRAGTIGES TO THE PRIVATE SEGTOR AND LOGAL COMMUNITIES}

Although ecosystem restoration is no longer explicitly stated in the Indonesia's Government Regulations, restoration ecosystem practices have been regularly incorporated into the management of protected forest and production forests. Companies receiving an ecosystem restoration business permit can target such practices for multiple services, including carbon sequestration.

To date, 16 restoration management units operate within a total area of 622,861 ha. These ecosystem restoration management units are found across five ecosystem types:, $24 \%$ in lowland forest , $14 \%$ in highland forest , $2 \%$ in mangroves, $59 \%$ in peatlands, and $1 \%$ in swamp (Ekonomi Bisnis, 2021). In addition, three of the companies have successfully provided a carbon conservation service: PT Ekosistem Khatulistiwa Lestari which manages 14,080 ha of forest in Kubu Raya - West Kalimantan, PT Rimba Makmur Utama which manages 157,875 ha of concessions in Katingan and Mentaya - Central Kalimantan, and PT Rimba Raya Conservation of $36,935.77$ ha in Seruyan, Central Kalimantan.

Ecosystem restoration activities are currently also expanding to other forest concession companies beyond ecosystem restoration permit holders, such as Industrial Plantation Forest concessions and Production Natural Forest concessions. Asia Pulp and Paper (APP) Sinar Mas is one example of the private sector's forest conservation policy. Ecosystem restoration has been adopted as part of APP's best management practices inside and outside its forest concession areas. There are at least four forest ecosystem restoration sites on private sector initiatives, specifically from APP Sinar Mas experience: concession area, degraded HCV and HCS area to be restored, the peak of peat dome, retirement area, and buffer zone.

This private sector progress complements and expands forest ecosystem restoration facilitated by the government. The Government of Indonesia coordinated by the Peat and Mangrove Restoration Agency has overseen interventions on 52,987 ha of peat ecosystem in 2020, developed 20,851 peat rewetting infrastructure units (boreholes, canal blocking, and backfilling), revegetated 1,187 ha, and delivered 1,174 packages of livelihoods revitalization and productive economic assistance. The Ministry of Environment and Forestry also reported that during 2015-2021, the government carried out large-scale land restoration on a total area of 4.69 million ha, including peat and mangroves (KLHK, 2021). These restoration progress were intended to increase the productivity of both forests and degraded land.

The Peat and Mangrove Restoration Agency actively involve local government and diverse local parties in restoration planning and implementation, as well as in the monitoring and evaluation processes. The Provincial Peat Restoration Team (Tim Restorasi Gambut Daerah) is established as an ad hoc institution led by the Governor and integrating several related institutions such as the Provincial Planning Agency, Forestry Office, Environment Office, Plantation Office, and Public Works Office. Some provinces also include academicians, adat representatives, NGOs, army, and judiciary office. In implementing restoration activities, they directly involve village communities and farmer groups as field implementers (Pantau Gambut, 2018).

The progress of peat restoration by both public and private initiatives demonstrates that both have played an active role in ecosystem restoration in Indonesia. However, the overall target that must be achieved is still large and requires more involvement of other parties. Until now, community participation in ecosystem restoration has only been seen to have a role in implementation in the field. Local communities have not yet been included in the initiation and planning of ecosystem restoration in their village areas.

One pilot initiative to encourage villagers in protecting and restoring peat ecosystem is through the Peat Care Village programme (Desa Peduli Gambut). The basic principle of the Peat Care Village is a framework for coordinating various village and regional development programmes/activities. It enables various local technical and socio-economic issues to be recognised and incorporated in planning as well as in execution of programmes: local wisdom and knowledge, disaster prevention response, formation of rural areas, spatial planning of villages and rural areas, identification of conflicts, regional clarity, legalization of rights and access, hydrology and land management, institutions and cooperation, economic empowerment. Through this programme, the goal is to significantly increase the number of participating villages (BRG, 2021).

Table 1. DPG built in Indonesia in 2020

\begin{tabular}{|c|c|c|}
\hline No & Province & Number of village \\
\hline 1 & Riau & 64 \\
\hline 2 & Jambi & 14 \\
\hline 3 & South Sumatera & 32 \\
\hline 4 & West Kalimantan & 37 \\
\hline 5 & Central Kalimantan & 77 \\
\hline 6 & South Kalimantan & 6 \\
\hline 7 & Papua & 2 \\
\hline
\end{tabular}

Source: BRG, 2021

\section{FUTURE CHALLENGES}

The inclusion of private sector and, increasingly, communities in ecosystem restoration has been widely 
reported. However, ecosystem restoration has not been a completely profitable business model for communities. The big future challenges are to ensure the sustainable financing for community participation and a productive empowerment model for restoration and the economy.

The key to tapping into both public and private sector funding opportunities for forest landscape restoration in particular lies in making it financially and economically attractive alongside the delivery of vital public goods and services. In light of economic liberalisation, private sector funding, including Payments for Ecosystem Services (PES), provides a lucrative opportunity for financing restoration activities. In terms of public funding, it will be increasingly important to mainstream forest landscape restoration into other programmes, including poverty reduction programmes (Mansourian et al., 2005). Lessons from other community financing models and empowerment approaches can be adopted for a successful community-based restoration model in Indonesia. These include outgrower schemes, PES, and Bio-rights.

\section{Private For-Profit Sources: Outgrower Schemes}

Outgrower schemes could be one option in promoting ecosystem restoration work through community participation. In an outgrower scheme, a company provides marketing and production services to farmers to grow trees on their land under specific agreements. Mansourian et al., (2005) reported that in 2002, around 12,000 smallholder tree growers were involved in outgrower schemes in South Africa on about 27,000 ha . The scheme also provides companies with positive publicity at a time when the distribution of land rights in South Africa is under critical review. Although community motivations are mostly focussed on cash income at harvest, the trees may also be seen as a route to carbon sequestration, as it is the non-wood forest product that is the main source of income for smallholders.

\section{Payments for Ecosystem Services}

One example of PES in action through ecosystem restoration is the Pimampiro Payment for Watershed Services Scheme, Ecuador (Mansourian, et al., 2005). Under a pioneering project for Ecuador, landowners in the Paluarco river sub-watershed are being paid to manage the forest in the watershed to protect water sources. In 2001, the municipality approved an ordinance that established the pilot project Water Regulation for the Payment of Environmental Services for Forest and Paramo Conservation. A fund was created to channel payments from beneficiaries (mostly domestic water users) to those providing good water quality through maintenance of forest cover upstream.

\section{Bio-rights}

Bio-rights were promoted by Eijk \& Kumar (2008) as a type of microfinance model. As such, the aim was to combine poverty alleviation and conservation efforts through the provision of microcredit for sustainable development. This approach supports local people to be actively involved in environmental restoration and conservation efforts.

- Phase 1 is the allocation of a financial loan to the community that can be used to develop activities to create sustainable income.

- $\quad$ Phase 2 is the repayment of loan not in the form of money, but in the form of environmental restoration, protection, and conservation services, which in this case is forest ecosystem restoration.

- $\quad$ Stage 3 is if the environmental recovery, protection, and conservation activities in stage 2 are deemed successful, then the loan will be converted into a pure grant, which can then be forwarded to other community members for further sustainable development activities.

\section{CONGLUSION}

Ecosystem restoration has been widely tackled in Indonesia, driven by both the government and the private sector. Although currently ecosystem restoration does not exist implicitly in Law and Government Regulation No. 23 of 2021, the practice of ecosystem restoration has become a recognized part of forest management in Indonesia. Efforts to mainstream ecosystem restoration must continue by creating new and feasible conservation business models and encouraging productive community empowerment.

Good progress has been made by the government in expanding the role of the private sector and the local community in implementing ecosystem restoration. However, the role of the community needs to be improved so that it is not only a supporting unit for the implementation of restoration, but also seen as the main instigator. Innovative business models need to be piloted and strengthened to make ecosystem restoration financially attractive for community groups.

\section{REFERENGES}

Austin, K.G., Schwantes, A., Gu, Y., Kasibhatla, P.S. (2019). What causes deforestation in Indonesia? Environmental Research Letters 14 (2019)

024007.https://doi.org/10.1088/1748-9326/aaf6db.

Bappenas. (2016). Indonesian Biodiversity Strategy and Action Plan 2015-2020. Jakarta: Kementerian Perencanaan Pembangunan Nasional/Bappenas.

BRG. (2021). Laporan Tahunan Badan Restorasi Gambut Tahun 2020. Jakarta: BRG.

Ditjen PKTL. (2020). Isu degradasi lahan (land degradation) di Indonesia. Jakarta: Ditjen Planologi Kehutanan dan Tata Lingkungan, KLHK. 
Eijk, P. van \& Kumar, R. (2008). Bio-rights in theory and practice. A financing mechanism for poverty alleviation and environmental conservation (Biorights dalam Teori dan Praktek. Sebuah Mekanisme Pembiayaan Pendanaan untuk Pengentasan Kemiskinan dan Konservasi Lingkungan). Wetlands International, Wstafingen, The Netherlands.

Ekonomi Bisnis. (2021) Komitmen Indonesia Cegah Perubahan Iklim Lewat Restorasi Ekosistem. https://ekonomi.bisnis.com/read/20210607/9/1402461/ko mitmen-indonesia-cegah-perubahan-iklim-lewat-restorasi-eko sistem. Retrieved October 2, 2021.

Griscom, B.W., Busch, J., Cook-Patton, S.C., Ellis, P.W., Funk, J., Leavitt, S.M., Lomax, G., Turner, W.R., Chapman, M., Engelmann, J., Gurwick, N.P., Landis, E., Lawrence, D., Malhi, Y., Murray, L.S., Navarrete, D., Roe, S., Scull, S., Smith, P., Streck, C., Walker, W.S., Worthington, T. 2020. National mitigation potential from natural climate solutions in the tropics. Phil. Trans. Roy. Soc. B 375: 20190126. http://dx.doi.org/10.1098/rstb.2019.0126.

Griscom, B.W., Adams, J., Ellis, P.W., Houghton, R.A., Lomax, G., Miteva, D.A.,Schlesinger, W.H., Shoch, D., Siikamäki, J.F., Smith, P., Woodbury, P., Zganjar, C., Blackman, A., Campari, J., Conant, R.T., Delgadol, C., Eliasa, P., Gopalakrishna, T., Hamsik, M.R., Herrero, M., Kiesecker, J., Landis, E., Laestadius, L, Leavitta, S.M.,Minnemeyer, S., Polaskyo, S., Potapov, P., Putz, F.E., Sanderman, J., Silvius, M.,Wollenbergs, E., Fargione, J. 2017.Natural climate solutions. PNAS, October 31, 2017, vol. 114 no. 44 p.11645-11650. www.pnas.org/cgi/doi/10.1073/pnas.17104 65114.

Hulvey, K. B., Standish, R. J., Hallett, L. M., Starzomski, B. M., Murphy, S. D., Nelson, C. R., Gardener, M. R., Kennedy, P. L., Seastedt, T. R., \& Suding, K. N. (2013). Incorporating novel ecosystems into management frameworks. Novel ecosystems: intervening in the new ecological world order, 157-171. West Sussex, UK: John Willey \& Sons, Ltd.

ITTO \& IUCN. (2005). Restoring forest landscapes: an introduction to the art and science of forest landscape restoration. ITTO Technical Series, 23.

IUCN. (2021). Science-based ecosystem restoration for the 2020s and beyond. Science Task Force for the UN Decade on Ecosystem Restoration. Gland, Switzerland: IUCN. 60pp.

IUCN \& WRI (2014). Pedoman Metode Evaluasi Kesempatan Restorasi (MEKAR): mengkaji kesempatan restorasi hutan dan bentang lahan pada tingkat nasional atau sub-nasional (Edisi Uji Coba). Gland, Swiss: IUGN.

JICA. (2014). Pedoman tata cara restorasi di kawasan konservasi hutan hujan tropis pegunungan dan hutan monsoon tropis. Jakarta: JICA.

KLHK. (2021). Babak Baru Restorasi Ekosistem. https://www.menlhk.go.id/site/single_post/3806/babak-bar u-restorasi-ekosistem. Retrieved on October 2, 2021
KLHK. (2018). Status hutan dan kehutanan Indonesia 2018. Jakarta: Kementerian Lingkungan Hidup dan Kehutanan. Jakarta.

Mansourian, S., Vallauri,D., Dudley,N. (Eds.) (2005). Forest Restoration in Landscapes: Beyond Planting Trees. New York: Springer (in cooperation with WWF International).

MoEF(Ministry of Environment and Forestry, Republic of Indonesia). (2020). The State of Indonesia's Forests 2020. Jakarta: Ministry of Environement and Forestry.

Motel , P.C., Pirard., and Combes, J-L. (2011). A methodology to estimate impacts of domestic policies on deforestation: compensated successful efforts for avoided deforestation (REDD). Hal Id.

Osaki, M., and Tsuji, N. (Eds) 2016. Tropical Peatland Ecosystems. Springer, Japan.

Pantau Gambut. (2018). Tugas Pembantuan Pemerintah Daerah dalam Restorasi Gambut: Temuan Implementasi 2018. Laporan Simpul Jaringan Pantau Gambut Indonesia. https://pantaugambut.id/uploads/default/articles/documen t/Laporan_Tugas_Pembantuan_Pemerintah.pdf. Retrieved October 3, 2021.

Republic of Indonesia. (2015). Indonesia - Land Degradation Neutrality National Report. UNCGD. Jakarta.

Rochmayanto, Y, Priatna, D, Mutaqin, M.Z. (Eds.) (2020). Strategi dan Teknik Restorasi Ekosistem Hutan Rawa Air Payau Tipe Lahan Marine Clay. Bogor: IPB Press.

Rochmayanto, Y, Priatna, D, Mutaqin, M.Z. (Eds.) (2021). Strategi dan Teknik Restorasi Ekosistem Hutan Rawa Gambut. Bogor: IPB Press.

Rowling, M. (2019). World 'losing battle' on 2020 goal to cut deforestation. Thomson Reuters Foundation News 12 September 2019. Di unduh pada tanggal 15 Juli 2020 dari https://news.trust.org/item/20190912123534-rteig/

Stanturf, J., Mansourian, S., Kleine, M. (Eds). (2017). Implementing Forest Landscape Restoration, A Practitioner's Guide. International Union of Forest Research Organizations, Special Programme for Development of Capacities (IUFRO-SPDG). Vienna, Austria. 128 p.

Suryadiputra, I N. N., Irwansyah, R. L., Iwan, T. C. W., \& Dipa, S. R. (2018). Restorasi lahan gambut di HLG Londerang dan Tahura Orang Kayo Hitam, Provinsi Jambi. Bogor: Wetlands International Indonesia.

Susetyo, P.D. (2021). Setelah Retorasi Ekosistem Tak Ada Lagi. Pojok Restorasi 15 Juni 2021. Forest Diggest. https://www.forestdigest.com/detail/1175/restorasi-ekosiste m-uu-cipta-kerja. Retrieved October 2, 2021.

WWF, (2009). Deforestation, forest degradation, biodiversity loss and CO2 emission in Riau, Sumatra, Indonesia. WWF Indonesia Technical Report. 